\title{
Effects of daphnetin on lipid metabolism, insulin resistance and oxidative stress in OA-treated HepG2 cells
}

\author{
YAYUN LIU*, LU LIAO*, YONG CHEN and FENGMEI HAN \\ Hubei Province Key Laboratory of Biotechnology of Chinese Traditional Medicine, \\ National and Local Joint Engineering Research Center of High-throughput Drug Screening Technology, \\ Hubei University, Wuhan, Hubei 430062, P.R. China
}

Received June 28, 2018; Accepted March 27, 2019

DOI: $10.3892 / \mathrm{mmr} .2019 .10139$

\begin{abstract}
Non-alcoholic fatty liver disease (NAFLD) is the most common cause of chronic liver disease, and has high rates of morbidity and mortality worldwide. Daphnetin (DAP) possesses notable antioxidative, anti-inflammatory and anticoagulant activities; DAP is an active ingredient extracted from Daphne Koreana Nakai. To investigate the effects and the underlying mechanism of DAP on NAFLD, we treated HepG2 cells with oleic acid (OA) and DAP simultaneously and non-simultaneously. In the simultaneous treatment condition, HepG 2 cells were co-treated with $0.5 \mathrm{mM}$ OA and DAP $(5,20$, and $50 \mu \mathrm{M})$ for $24 \mathrm{~h}$. In the non-simultaneous treatment conditions, HepG2 cells were pretreated with $0.5 \mathrm{mM}$ OA for $24 \mathrm{~h}$, and then treated with DAP $(5,20$ and $50 \mu \mathrm{M}$ ) for $24 \mathrm{~h}$. Following the aforementioned treatments, the biochemical indexes associated with NAFLD were measured as follows: i) The intracellular contents of triglyceride (TG), reactive oxygen species (ROS) and fluorescent glucose 2-[N-(7-nitrobenz-2-oxa-1,3-diazol-4-yl) amino]-2-deoxyglucose were analyzed with corresponding detection kits; and ii) the cellular expression levels of glycolipid metabolism- and oxidative stress-related genes, including 5'AMP-activated protein kinase (AMPK), sterol regulatory element-binding protein-1C (SREBP-1C), patatin-like phospholipase domain-containing protein 3 (PNPLA3), peroxisome proliferator-activated receptor $\alpha(\operatorname{PPAR} \alpha)$, phosphoinositide 3-kinase (PI3K), protein kinase B (AKT),
\end{abstract}

Correspondence to: Professor Yong Chen or Professor Fengmei Han, Hubei Province Key Laboratory of Biotechnology of Chinese Traditional Medicine, National and Local Joint Engineering Research Center of High-throughput Drug Screening Technology, Hubei University, 368 Youyi Avenue, Wuchang, Wuhan, Hubei 430062, P.R. China

E-mail: cy101610@qq.com

E-mail: 1597114874@qq.com

${ }^{*}$ Contributed equally

Key words: daphnetin, non-alcoholic fatty liver, HepG2 cells, glycolipid metabolism, oxidative stress nuclear factor-like 2 (Nrf2), cytochrome P450 (CYP) 2E1 and CYP4A were determined by reverse transcription-quantitative polymerase chain reaction and western blotting. The results revealed the potential mechanism underlying the effects of DAP on NAFLD in vitro: i) By increasing the phosphorylation of AMPK, DAP inhibited the expression of SREBP-1C and PNPLA3, and induced that of PPAR $\alpha$. Lipid accumulation within hepatocytes was reduced; ii) by upregulating PI3K expression and pAKT/AKT levels, DAP may alleviate insulin resistance and promote hepatocellular glucose uptake; and iii) by upregulating the expression of Nrf2, DAP downregulated the expression of CYP2E1 and CYP4A, and the levels of reactive oxygen species in hepatocytes.

\section{Introduction}

Non-alcoholic fatty liver disease (NAFLD) is the most common cause of chronic liver disease, with high rates of morbidity and mortality worldwide (1). NAFLD is characterized by excessive lipid accumulation in hepatocytes, and is considered as the origin of cirrhosis (2). The pathogenesis of NAFLD remains unclear and the 'two hit theory' was proposed for the pathogenic mechanism. Briefly, lipid accumulation in the liver associated with obesity and insulin resistance (IR) was reported as the 'first hit theory' in patients with NAFLD. This results in hepatic steatosis and can provides sufficient reaction conditions for oxidative stress, increasing the susceptibility of hepatocytes to endogenous and exogenous damage. The 'second hit theory' involves hepatic oxidative stress and lipid peroxidation, and the secretion of inflammatory cytokines, which mediates the pathological progression of steatosis to inflammation, fibrosis and necrosis in liver cells $(3,4)$. Notably, $20-30 \%$ of adults suffer from NAFLD and it has been suggested that it may become the leading cause of liver transplantation within the next few decades (5). NAFLD is closely associated with the growing epidemic of obesity and cardiovascular mortality, and NAFLD-associated complications are a major cause of death $(6,7)$. At present, there is no effective drug for treating NAFLD in clinical practice. Some antioxidants, insulin sensitizers and lipid-lowering drugs have been applied in clinical trials for the treatment of NAFLD/non-non-alcoholic steatosis (NASH) $(8,9)$. 
As an active ingredient of Daphne Koreana Nakai (10), daphnetin (DAP; Fig. 1) has notable antioxidative, anti-inflammatory and anticoagulant activities (10-12). Generally, coumarin compounds markedly lower blood glucose and lipid levels, and protect the liver against oxidative stress and inflammation. $(13,14)$. Recently, Lv et al (12) reported that DAP could ameliorate mitochondrial dysfunction and cell death by upregulating nuclear factor-like 2 (Nrf2)-associated antioxidant signaling pathways and reducing the expression of kelch-like epichlorohydrin related protein-1, thus enhancing the expression of antioxidant reaction elements and alleviating oxidative damage-associated toxicity (12). Yu et al reported that proinflammatory mediators induced by lipopolysaccharides or $\beta$-amyloid, including interleukin- 1 and tumor necrosis factor- $\alpha$, could be inhibited by DAP. DAP may also regulate a series of intracellular signaling pathways, including I $\mathrm{B}$ kinase, mitogen-activated protein kinases (MAPKs) and phosphoinositide 3-kinase (PI3K)/protein kinase B (AKT) to reduce the microglial activation and proinflammatory response (15). Therefore, we proposed that DAP may possess lipid-reducing activities similar to other coumarin compounds. At present, the effect of DAP on NAFLD has not been reported. The present study aimed to investigate the effects of simultaneous and non-simultaneous treatment, and the underlying mechanism of DAP on NAFLD-related symptoms in oleic acid (OA)-treated HepG2 cells.

\section{Materials and methods}

Materials. DAP (cat. no. R-0070161216, high-pressure liquid chromatography-determined grade $>98 \%$, Chengdu Herbpurify, Co., Ltd.) and OA (cat. no. S104196, Aladdin) were employed in the present study. In addition, rabbit anti-human polyclonal antibodies, including peroxisome proliferator-activated receptor $\alpha$ (PPAR $\alpha$; cat. no. WL00978), sterol regulatory element-binding protein-1C (SREBP-1C; cat. no. WL01314), AKT (cat. no. WL0003b), phosphorylated (p)AKT (cat. no. WLP001), PI3K (cat. no. WL02240), Nrf2 (cat. no. WL02135), 5'AMP-activated protein kinase (AMPK; cat. no. WL03366) antibodies were obtained from Wanlei Biotechnology. Rabbit anti-human polyclonal antibodies, including anti-cytochrome P450 4A11 (CYP4A; cat. no. ab140635), anti-patatin-like phospholipase domain-containing protein 3 (PNPLA3; cat. no. ab81874) and anti-p 5'AMP-activated protein kinase (pAMPK; cat. no. ab23875) were purchased from Abcam. Additionally, rabbit anti-human polyclonal antibody CYP 2E1 (cat. no. BA1774-2, Wuhan Boster Biological Technology, Ltd.); mouse anti-human monoclonal $\beta$-actin antibody (cat. no. sc-47778, Santa Cruz Biotechnology, Inc.); Dulbecco Minimal Eagle's medium (DMEM; cat. no. 12800-017, Gibco; Thermo Fisher Scientific, Inc.); 2-[N-(7-nitrobenz-2-oxa-1,3-diazol-4-yl) amino]-2-deoxyglucose (2-NBDG; cat. no. 1922861, Invitrogen; Thermo Fisher Scientific, Inc.); Reverse transcription kit (cat. no. FSQ-101, Toyobo Life Science); SYBR Green I real-time PCR kit (172-5124, Bio-Rad Laboratories, Inc.); BCA protein assay kit (cat. no. 23225, Thermo Fisher Scientific, Inc.) were employed. Furthermore, radioimmunoprecipitation assay (RIPA; cat no. P0013B), BeyoECL Plus (cat. no. P0018), Reactive oxygen species (ROS) detection kit (cat. no. S0033), PMSF (cat. no. ST506) were obtained from Beyotime Institute of Biotechnology. Triglyceride (TG) detection kit (cat. no. E1013, Applygen Technologies, Inc.); 3-(4,5-dimethylthiazol-2-yl)-2,5-diphenyltetrazolium bromide (MTT; cat. no. M2128); dimethyl sulfoxide (DMSO; cat. no. D5879 were purchased from Sigma-Aldrich (Merck KGaA). Protease cocktail (cat. no. 04693132001) and phosphatase inhibitors (cat. no. 04906837001) were obtained from Roche Diagnostics. The human hepatoblastoma cell line HepG2 was acquired from the Culture Collection Center of Wuhan University.

Cell culture and drug treatment. HepG2 cells were cultured in DMEM and logarithmic phase cells were inoculated into 6-well plates $\left(2 \times 10^{5}\right.$ cells/well) at the condition of $37^{\circ} \mathrm{C}$ and $5 \%$ $\mathrm{CO}_{2}$. After the cells adhered, HepG2 cells were treated with OA (dissolved in methanol) and DAP (dissolved in DMSO) simultaneously and non-simultaneously. In the simultaneous treatment condition, cells were co-treated with $0.5 \mathrm{mM} \mathrm{OA}$ and DAP $(5,20$ or $50 \mu \mathrm{M})$ for $24 \mathrm{~h}$ at $37^{\circ} \mathrm{C}$. The control group was treated with $0.3 \%$ methanol and $0.1 \%$ DMSO for $24 \mathrm{~h}$ at $37^{\circ} \mathrm{C}$; the OA group was treated with $0.5 \mathrm{mM} \mathrm{OA}$ and $0.1 \%$ DMSO for $24 \mathrm{~h}$ at $37^{\circ} \mathrm{C}$. In the non-simultaneous treatment condition, cells were pretreated with $0.5 \mathrm{mM} \mathrm{OA}$ for $24 \mathrm{~h}$ at $37^{\circ} \mathrm{C}$, and then treated with DAP $(5,20$ or $50 \mu \mathrm{M})$ for $24 \mathrm{~h}$ at $37^{\circ} \mathrm{C}$. The control group was treated with $0.3 \%$ methanol for $24 \mathrm{~h}$ at $37^{\circ} \mathrm{C}$ and then treated with $0.1 \%$ DMSO for $24 \mathrm{~h}$ at $37^{\circ} \mathrm{C}$; the OA group was treated with $0.5 \mathrm{mM} \mathrm{OA}$ for $24 \mathrm{~h}$ at $37^{\circ} \mathrm{C}$ and then treated with $0.1 \%$ DMSO for $24 \mathrm{~h}$ at $37^{\circ} \mathrm{C}$. Each group of cells was analyzed in triplicate and the experiments were repeated three times.

Cell viability assay. When cells attained $85-90 \%$ confluence, cells were seeded into a 96-well plate at a density of $5 \times 10^{3}$ cells/well. After the cells are pretreated with OA for $24 \mathrm{~h}$ at $37^{\circ} \mathrm{C}$ and then treated with $200 \mu \mathrm{l}$ culture medium containing DAP $(5,20,50$ and $100 \mu \mathrm{M})$ for $24 \mathrm{~h}$ at $37^{\circ} \mathrm{C}$ (five replicate wells per group), the supernatant was discarded, and the mixture of $20 \mu \mathrm{l}$ MTT and $180 \mu \mathrm{l}$ PBS were added into each well at $37^{\circ} \mathrm{C}$ for $4 \mathrm{~h}$. Then, $150 \mu \mathrm{l}$ DMSO was added to each well to dissolve the purple formazan crystals, and the absorbance of each well was detected at $570 \mathrm{~nm}$ using a microplate reader. Each group of cells was analyzed in triplicate and the experiments were repeated three times.

Measurement of triglyceride (TG) levels. Following treatment, the cells were collected, lysed using the lysis buffer in the TG detection kit at $37^{\circ} \mathrm{C}$ for $10 \mathrm{~min}$ and were then centrifuged at $12,000 \mathrm{x} \mathrm{g}$ for $5 \mathrm{~min}$ at $4^{\circ} \mathrm{C}$. The contents of TG and protein in each well were measured with TG and BCA detection kits according to the manufacturer's instructions, respectively. The ratio of TG to protein was calculated to express the relative TG level. Each group of cells was analyzed in triplicate and the experiments were repeated three times.

Measurement of 2-NBDG levels. Following treatment, $1 \times 10^{6}$ cells in each well were cultured in glucose-free DMEM for $3 \mathrm{~h}$ at $37^{\circ} \mathrm{C}$ and then with $50 \mu \mathrm{M}$ 2-NBDG for $30 \mathrm{~min}$ at $37^{\circ} \mathrm{C}$. The cells in each well were collected, the fluorescence intensity was measured at excitation/emission wavelengths 


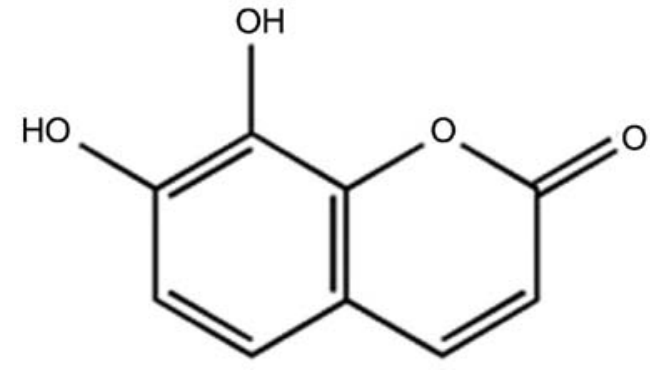

Figure 1. Chemical structure of daphnetin.

of 485/535 nm, respectively. The protein concentration was detected as aforementioned. The ratio of fluorescence intensity to protein content of each well indicated the relative glucose uptake rate. Each group of cells was analyzed in triplicate and the experiments were repeated three times.

Measurement of ROS levels. Following treatment, $1 \times 10^{6}$ cells in each well wereincubated with $10 \mu$ Mdichlorodihydro-fluorescein diacetate for $30 \mathrm{~min}$ at $37^{\circ} \mathrm{C}$, and then collected. The fluorescence value was measured at excitation/emission wavelengths of $485 / 535 \mathrm{~nm}$ and the protein concentration of cells were detected as aforementioned. The ratio of the fluorescence value to the protein concentration indicated the relative ROS content in each well. Each group of cells was analyzed in triplicate and the experiments were repeated three times.

Reverse transcription-quantitative polymerase chain reaction (RT-qPCR). Following treatment, cells in each well were collected and the total RNA was extracted with TRIzol reagent (Invitrogen; Thermo Fisher Scientific, Inc.). The bands of 28S, $18 \mathrm{~S}$ and $5 \mathrm{~S}$ were separated by $1 \%$ agarose gel electrophoresis for the analysis of RNA integrity. The absorbance at 260 and $280 \mathrm{~nm}$ was detected by spectrophotometry for the analysis of RNA purity. Then $2 \mu \mathrm{g}$ of total RNA was reverse transcribed into $20 \mu \mathrm{l}$ cDNA using a reverse transcription kit at the following conditions: $37^{\circ} \mathrm{C}$ for $5 \mathrm{~min}, 95^{\circ} \mathrm{C}$ for $30 \mathrm{~min}$. qPCR was performed using the SYBR Green I real-time PCR kit for 39 cycles at the following conditions: Pre-denaturation at $95^{\circ} \mathrm{C}$ for $5 \mathrm{~min}$, denaturation at $95^{\circ} \mathrm{C}$ for $30 \mathrm{sec}$, annealing at $58.4^{\circ} \mathrm{C}$ for $30 \mathrm{sec}$ and extension at $72^{\circ} \mathrm{C}$ for $30 \mathrm{sec}$. The primer sequences of SREBP-1C, PNPLA3, PPAR $\alpha$ and $\beta$-actin were presented in Table I. Each group of cells was analyzed in triplicate and the experiments were repeated three times. $\beta$-actin was used as a reference gene. The relative quantification of mRNA expression levels was determined using the $2^{-\Delta \Delta \mathrm{Cq}}$ method (16).

Western blotting. Following treatment, cells were lysed with RIPA lysis buffer [containing $50 \mathrm{mM}$ Tris ( $\mathrm{pH} 7.4$ ), $150 \mathrm{mM}$ $\mathrm{NaCl}, 1 \%$ Triton $\mathrm{X}-100,1 \%$ sodium deoxycholate, $0.1 \%$ SDS, sodium orthovanadate, sodium fluoride, EDTA and leupeptin], protease and phosphatase inhibitors on ice for $40 \mathrm{~min}$. The lysate was centrifuged at $12,000 \mathrm{x}$ g at $4^{\circ} \mathrm{C}$ for $10 \mathrm{~min}$, and the protein content in the supernatant was determined using a BCA kit. A total of 20-70 $\mu \mathrm{g}$ of total protein was separated by SDS-PAGE (10\% separation gel; 5\% concentration gel) and transferred onto polyvinylidene difluoride membranes. The membranes were blocked with $5 \%$ non-fat dry milk at $37^{\circ} \mathrm{C}$
Table I. Primers for reverse transcription-quantitative polymerase chain reaction.

\begin{tabular}{ll}
\hline Primer & \multicolumn{1}{c}{ Sequence (5'-3') } \\
\hline PNPLA3 & F: CTGTACCCTGCCTGTGGAAT \\
& R: TCGAGTGAACACCTGTGAGG \\
SREBP-1C & F: CGACATCGAAGACATGCTTCAG \\
& R:CGACATCGAAGACATGCTTCAG \\
PPAR $\alpha$ & F: GGGGACATTCCTGTGTTCAG \\
$\beta$-actin & R: CAAGTAGAGTGCCAGGCAAG \\
& F: TCACCCACACTGTGCCCATCT \\
& R: CAGCGGAACCGCTCATTGCC
\end{tabular}

F, forward; R, reverse; PNPLA3, patatin-like phospholipase domain-containing protein; PPAR $\alpha$, peroxisome proliferator-activated receptor $\alpha$; SREBP-1C, sterol regulatory element-binding protein-1C.

for $2 \mathrm{~h}$, and then incubated at $4^{\circ} \mathrm{C}$ with the different primary antibodies ( $\beta$-actin, 1:1,000; PNPLA3, 1:1,000; SREBP-1C, 1:500; PPAR $\alpha, 1: 500 ;$ PI3K, 1:500; pAKT, 1:500; AKT, 1:500; CYP2E1, 1:500; CYP4A, 1:1,000; Nrf2, 1:500 and pAMPK, 1:1,000) overnight. After washing the membrane with $500 \mu 1$ Tween-20/1 1 Tris-buffered saline (10 min for four times), the membranes were incubated at room temperature with secondary antibodies [horseradish-peroxidase (HRP)-goat-anti-mouse $\lg G(1: 8,000)$ and HRP-goat-anti-rabbit $\lg G(1: 8,000)]$ for $1 \mathrm{~h}$. The immunoblots were examined using an enhanced chemiluminescence system and ChemiDoc ${ }^{\mathrm{TM}}$ MP Imaging System (Bio-Rad Laboratories, Inc.). Finally, ImageJ software (64-bit Java 1.8.0_112; National Institutes of Health) was used for the quantitative gray scale analysis of the bands in the X-ray film. Each group of cells was analyzed in triplicate and the experiments were repeated three times.

Statistical analysis. Data were obtained from at least three experimental repeats and presented as the mean \pm standard deviation. The grouped data were analyzed with SPSS 17.0 (SPSS, Inc., Chicago, IL, USA). Statistical significance was analyzed by analysis of variance and a Tukey's post hoc test for multiple comparisons. $\mathrm{P}<0.05$ considered to indicate a statistically significant difference.

\section{Results}

Cytotoxicity of DAP on HepG2 cells. The results of the MTT assay (Fig. 2) revealed that DAP had no significant effects on the viability of OA-pretreated HepG2 cells in the range of 5-100 $\mu \mathrm{M}$ DAP.

Effects of DAP on lipid metabolism in OA-treated HepG2 cells. The effects of OA and DAP co-treatment on the lipid metabolism of HepG2 cells were analyzed. Compared with the control group, the content of TG, as well as the levels of the mRNA and protein expression of SREBP-1C and PNPLA3 were significantly increased (Fig. 3). In addition, the mRNA and protein expression of PPAR $\alpha$ along with the phosphorylation of AMPK were significantly downregulated in the 


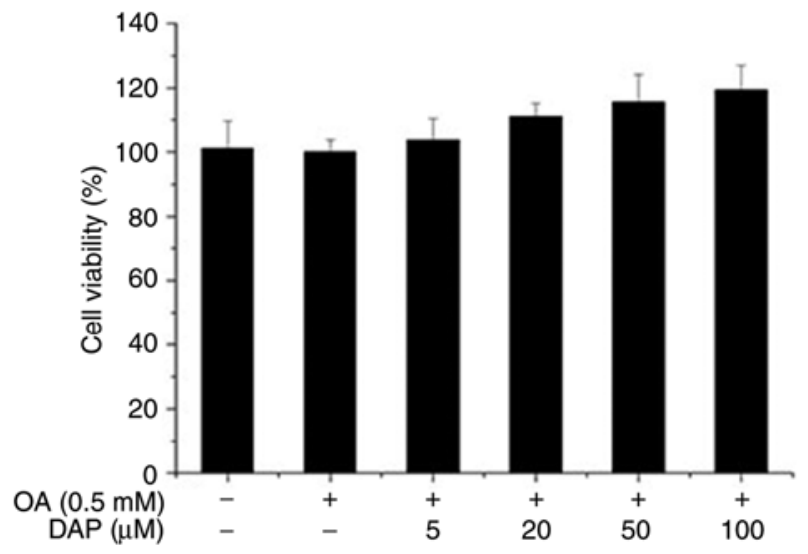

Figure 2. Effects of increasing concentrations of DAP on the viability of HepG2 cells treated with OA for $24 \mathrm{~h}$ and the control group, which was treated with $0.3 \%$ methanol for $24 \mathrm{~h}$ followed by $0.1 \%$ DMSO for $24 \mathrm{~h}$. The OA group was treated with $0.5 \mathrm{mM}$ OA for $24 \mathrm{~h}$ and $0.1 \%$ DMSO for 24 . Cell viability was determined via an MTT assay. DMSO, dimethyl sulfoxide; OA, oleic acid.

OA-treated group compared with the control (Figs. 3 and 4) compared with the control under both treatment conditions. Compared with the OA-treated group, co-treatment with 20 or $50 \mu \mathrm{M}$ DAP and OA significantly decreased the content of TG and the expression of PNPLA3 under simultaneous treatment conditions (Fig. 3A and B). In addition, increased the mRNA and protein expression of PPAR $\alpha$, and the phosphorylation of AMPK in a dose-dependent manner simultaneous treatment conditions (Figs. 3 and 4). Additionally, the mRNA expression levels of SREBP-1C were also downregulated in a dose-dependent manner (Fig. 3A), while the protein expression of SREBP-1C was significantly decreased following treatment with $50 \mu \mathrm{M}$ DAP, or 20 and $50 \mu \mathrm{M}$ DAP in the simultaneous and non-simultaneous treatment condition respectively (Fig. 4A).

Furthermore, the effects on the lipid metabolism under non-simultaneous treatment conditions revealed a notably similar trend with that of the co-treatment conditions (Fig. 3). DAP markedly affected the mRNA expression levels of PNPLA3 in the non-simultaneous treatment (Figs. 3 and 4). The differing results under the two treatment conditions may be associated with the culturing of cells for $>24 \mathrm{~h}$ prior to non-simultaneous treatment. In the extra $24 \mathrm{~h}$, cells may undergo self-repair and division, in which the newly formed cells were not incubated with OA.

Effects of DAP on IR in OA-treated HepG2 cells. Compared with the OA-treated group, $50 \mu \mathrm{M}$ DAP significantly increased the glucose uptake ability, while the protein expression levels of PI3K and pAKT/AKT in the case of the co-treatment conditions (Fig. 5). In addition, compared with the OA-treated group under non-simultaneous treatment conditions, DAP promoted the glucose uptake ability and the expression of pAKT/AKT in a dose-dependent manner; that of PI3K increased following treatment with 20 and $50 \mu \mathrm{M}$ DAP (Fig. 5).

Effects of DAP on oxidative stress in OA-treated HepG2 cells. Under the simultaneous and non-simultaneous treatment conditions, the content of ROS and the protein expression of
CYP2E1 and CYP4A in OA-treated group were significantly increased than in the control group, while the protein expression of Nrf2 in OA-treated group were significantly reduced than in the control group (Fig. 6A). Following DAP treatment for $24 \mathrm{~h}$ under both treatment conditions, the content of ROS, and the protein expression of CYP2E1 and CYP4A decreased, while Nrf2 expression was significantly increased compared with the OA-treated group (Fig. 6A and B).

\section{Discussion}

NAFLD comprises three forms, including steatosis, nonalcoholic steatohepatitis and cirrhosis (17). Fatty degeneration is characterized by the accumulation of $>95 \%$ TG in hepatocytes $(18,19)$. OA-treated HepG2 cells serves as a classic in vitro model for the study of NAFLD (20-22). In the present study, by using this particular in vitro model, we investigated the simultaneous and non-simultaneous effects of DAP on the lipid metabolism, IR and oxidative stress of OA-treated HepG2 cells.

To determine the optimal concentration of DAP for HepG2 cells, we evaluated the toxicity of DAP to HepG2 cells with $\mathrm{OA}$. The indicators analyzed in the present study were investigated in the presence of OA; treatment with OA has been reported not to exhibit cytotoxic effects on the viability of HepG2 and L02 cells; OA has been used in numerous investigations (20-22).

The liver is a key organ that regulates energy homeostasis of the body, and liver dysfunction is often associated with an imbalance in systemic metabolism (23). AMPK is a key factor in the development of NAFLD (24), and can negatively regulate SREBP-1C to reduce the formation of free fatty acids (FFAs) (25); SREBP-1C can regulate the IR pathway (26). In addition, SREBP-1C is an important transcription factor that regulates cholesterol homeostasis in hepatocytes and serves a crucial role in the regulation of NAFLD-related lipid metabolism (27). PNPLA3 is a determinant of TG accumulation in the liver and is regulated by SREBP-1C (28). PPAR $\alpha$ is a transcription factor that participates in the $\beta$-oxidation of FFA (29). Our results revealed that DAP inhibited the upregulated expression of SREBP-1C and PNPLA3, as well as the downregulation of PPAR $\alpha$ and $p A M P K$ induced by OA-treatment. This suggested that DAP could alleviate lipid accumulation by promoting the phosphorylation of AMPK, and regulating the expression of SREBP-1C, PNPLA3 and PPAR $\alpha$ in OA-treated HepG2 cells.

Energy metabolism is mainly regulated by insulin, in which insulin binds to its receptors located at the cell surface, activating $\beta$-tyrosine kinase to induce insulin signaling (30). Patients with NAFLD usually suffer from IR and exhibit decreased insulin sensitivity in the liver and adipose tissues (31-33). IR causes the hydrolysis of TGs in adipocytes, and produces large quantities of FFAs, which increases plasma FFA levels and exacerbates lipid accumulation in hepatocytes (34). Furthermore, IR leads to increased blood glucose levels by lowering the glucose absorption of muscle cells and reducing the glucose reserve of liver cells $(35,36)$. There are two main signaling pathways that utilize insulin receptors, one is the PI3K/AKT signaling pathway, the other is the MAPK pathway (37). The upregulation of PI3K/AKT expression is conducive to increased 

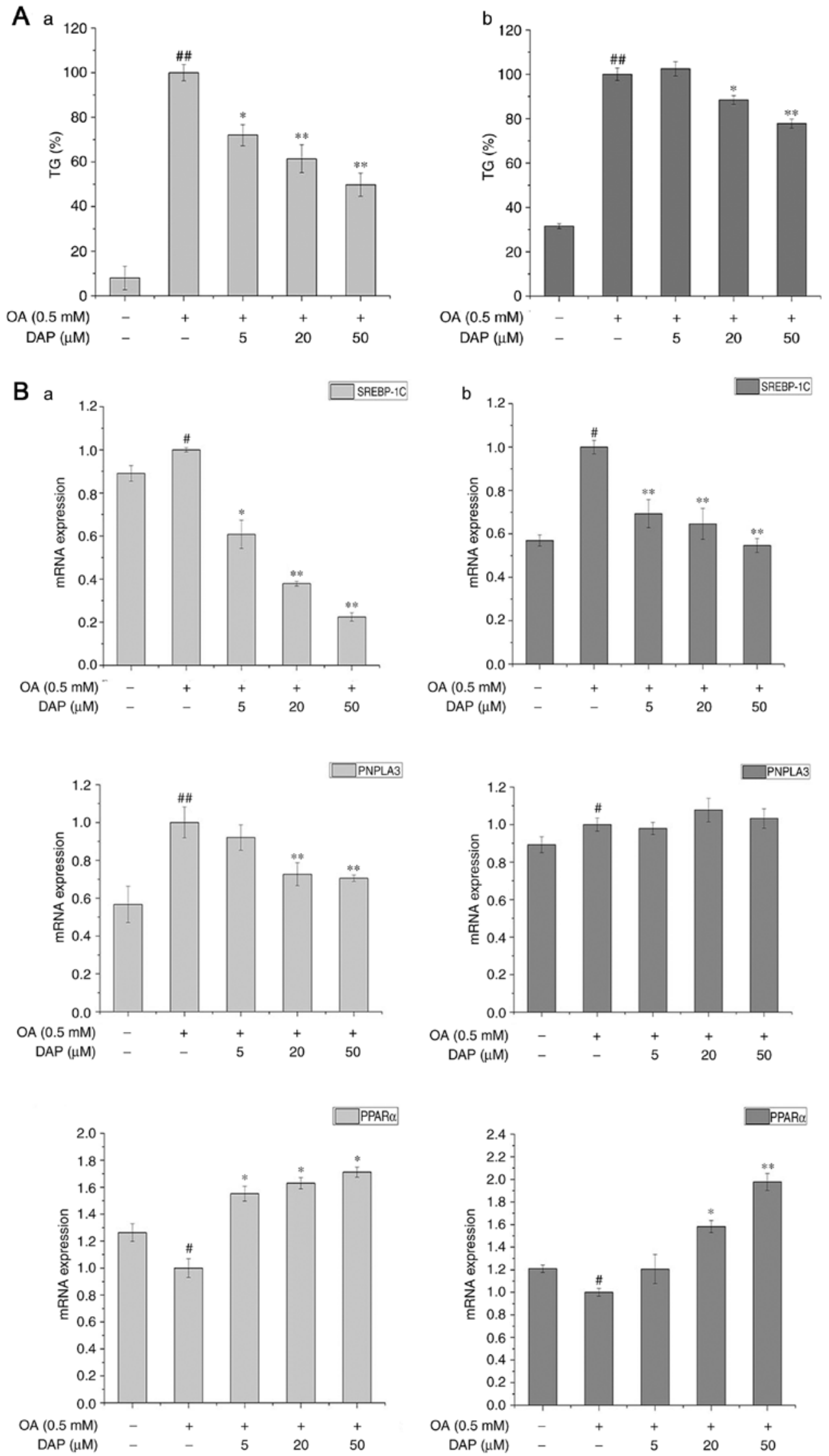

Figure 3. Effects of increasing concentrations of DAP for $24 \mathrm{~h}$ on the cellular TG and the mRNA expression levels of PPAR $\alpha$, PNPLA3, SREBP-1C. TG levels in HepG2 cells following (A-a) simultaneous treatment with OA and DAP and (A-b) non-simultaneous treatment. The expression of SREBP-1C, PNPLA3 and PPAR $\alpha$ following (B-a) simultaneous and (B-b) non-simultaneous treatment with OA and DAP was determined via reverse transcription-quantitative polymerase chain reaction. The control group under simultaneous treatment conditions was treated with $0.3 \%$ methanol and $0.1 \%$ DMSO for $24 \mathrm{~h}$; the OA group was treated with $0.5 \mathrm{mM} \mathrm{OA}$ and $0.1 \%$ DMSO for $24 \mathrm{~h}$. The control group under the non-simultaneous treatment was treated with $0.3 \%$ methanol for $24 \mathrm{~h}$ and then with $0.1 \%$ DMSO for $24 \mathrm{~h}$; the OA group was treated with $0.5 \mathrm{mM} \mathrm{OA}$ for $24 \mathrm{~h}$ and then with $0.1 \%$ DMSO for $24 \mathrm{~h} .{ }^{~} \mathrm{P}<0.05,{ }^{\# \#} \mathrm{P}<0.01 \mathrm{vs}$. control group; ${ }^{*} \mathrm{P}<0.05,{ }^{* *} \mathrm{P}<0.01$ vs. $\mathrm{OA}$ group. 
A a

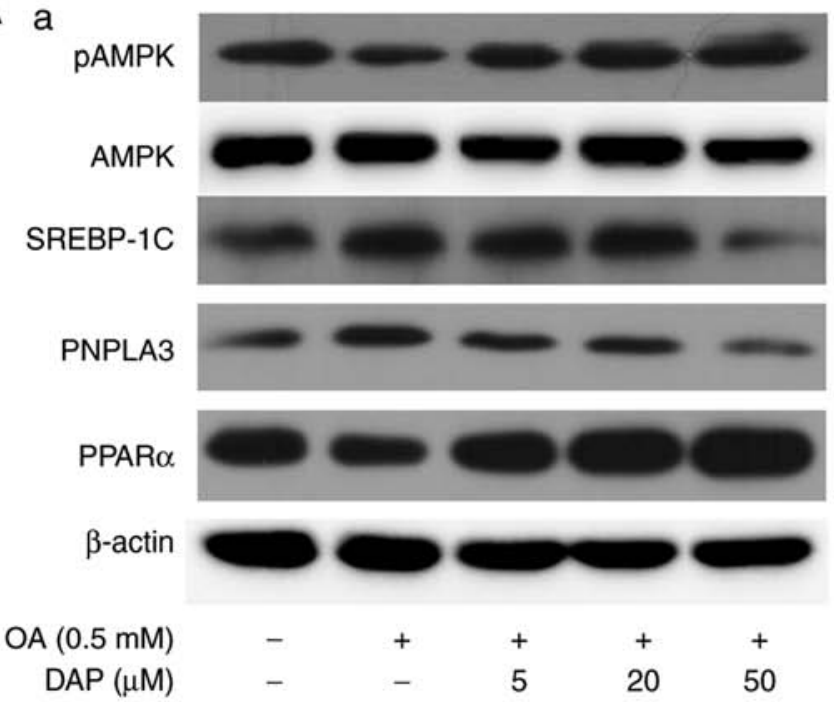

c

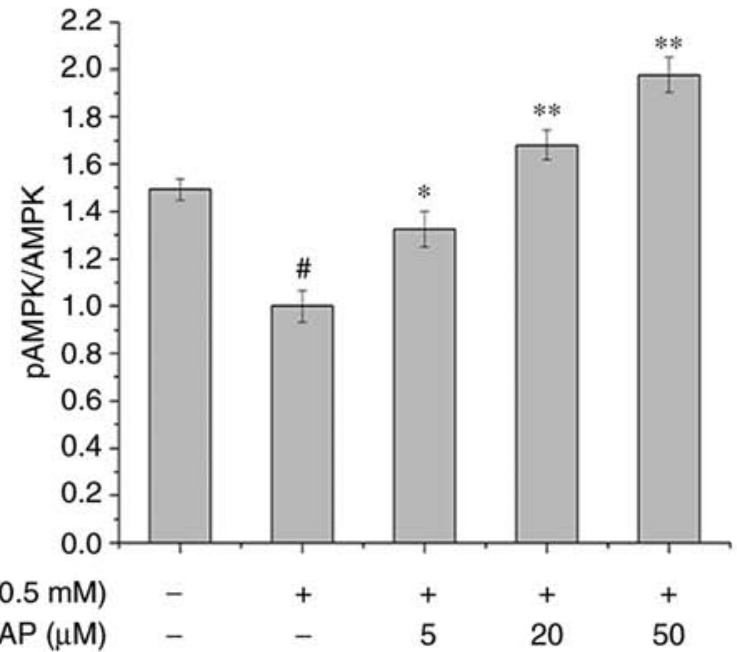

b

PAMPK

AMPK

SREBP-1C

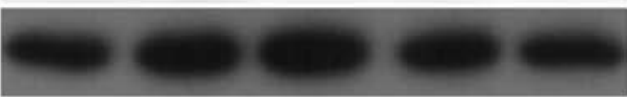

PNPLA3

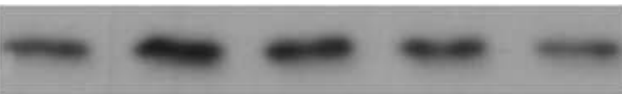

PPAR $\alpha$

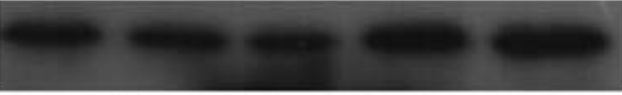

$\beta$-actin

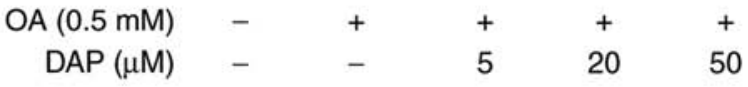

d

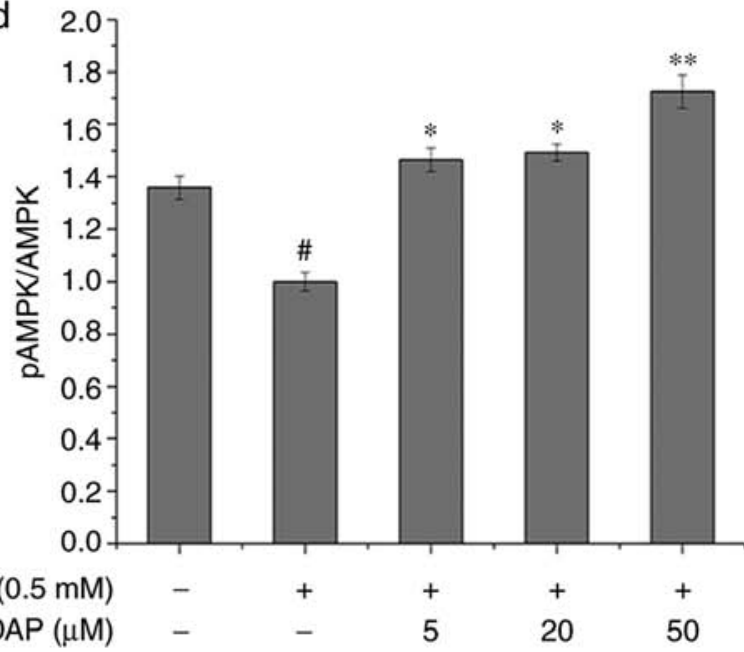

e

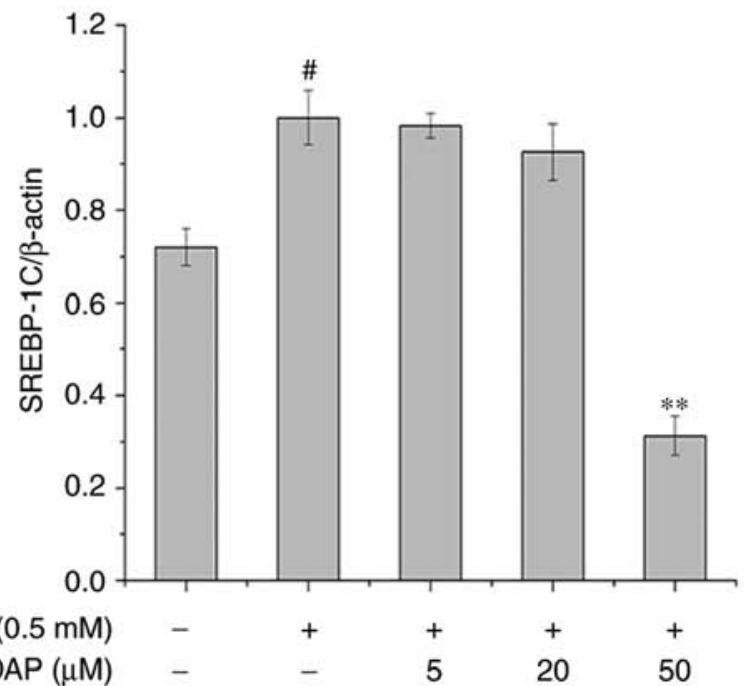

f

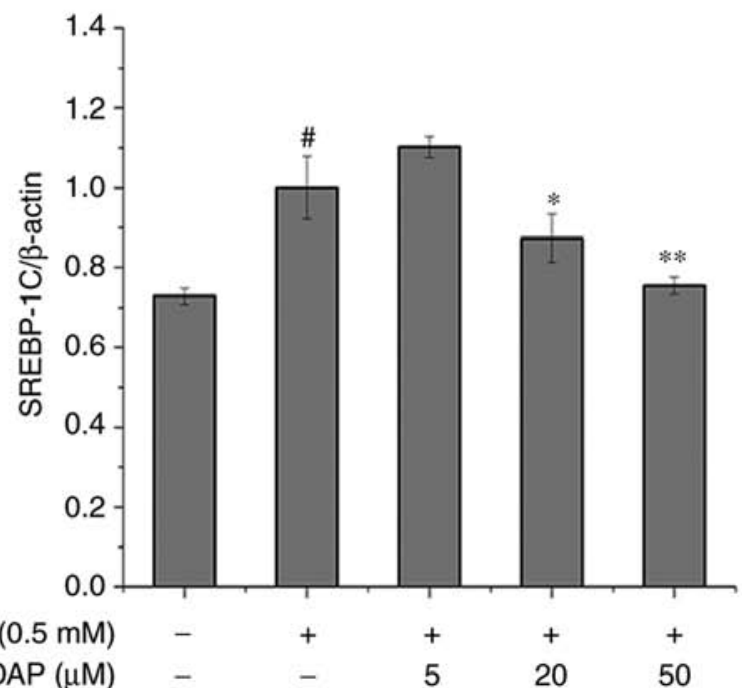

Figure 4. Effect of increasing concentrations of DAP for $24 \mathrm{~h}$ on the protein expression of pAMPK, PPAR $\alpha$, PNPLA3 and SREBP-1C in HepG2 cells. Western blot analysis following (A-a) simultaneous and (A-b) non-simultaneous treatment with OA and DAP. Densitometry analysis of (A-c and -d) pAMPK/AMPK, (A-e and -f) SREBP-1c. The control group under simultaneous treatment conditions was treated with $0.3 \%$ methanol and $0.1 \%$ DMSO for $24 \mathrm{~h}$; the OA group was treated with $0.5 \mathrm{mM} \mathrm{OA}$ and $0.1 \%$ DMSO for $24 \mathrm{~h}$. The control group under non-simultaneous treatment conditions was treated with $0.3 \%$ methanol for $24 \mathrm{~h}$ and then with $0.1 \%$ DMSO for $24 \mathrm{~h}$; the OA group was treated with $0.5 \mathrm{mM} \mathrm{OA}$ for $24 \mathrm{~h}$ and then with $0.1 \%$ DMSO for $24 \mathrm{~h}$. The bands of the western blots generated in our study were obtained from the same protein samples, but were not all run in the same experiment on the same gel. ${ }^{\text {}} \mathrm{P}<0.05 \mathrm{vs}$. control group; ${ }^{*} \mathrm{P}<0.05,{ }^{* *} \mathrm{P}<0.01$ vs. OA group. 

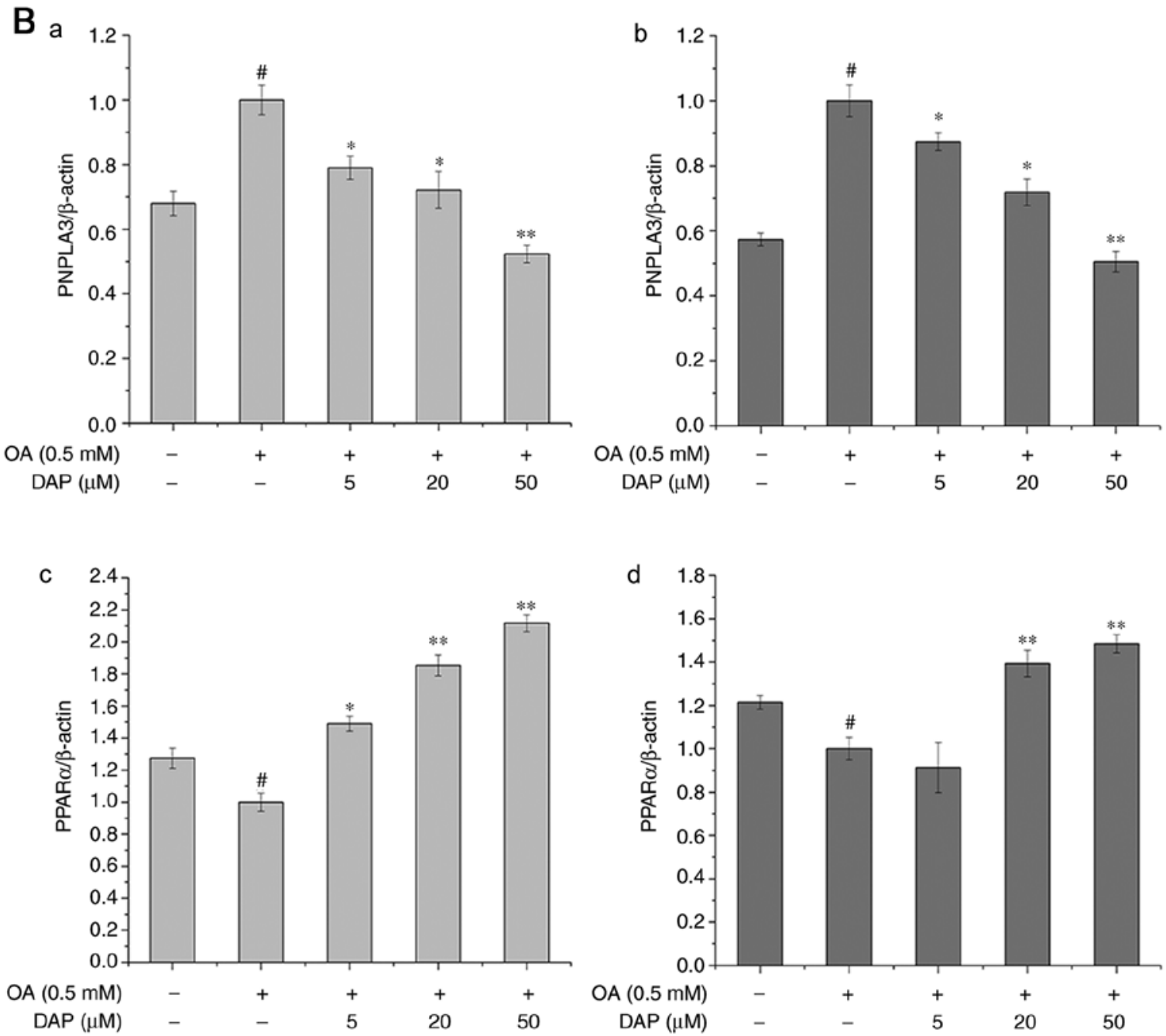

Figure 4. Continued. Effect of increasing concentrations of DAP for $24 \mathrm{~h}$ on the protein expression of pAMPK, PPAR $\alpha$, PNPLA3 and SREBP-1C in HepG2 cells. Densitometry analysis of (B-a and -b) PNPLA3 and (B-c and -d) PPAR $\alpha$. The control group under simultaneous treatment conditions was treated with $0.3 \%$ methanol and $0.1 \%$ DMSO for $24 \mathrm{~h}$; the OA group was treated with $0.5 \mathrm{mM} \mathrm{OA}$ and $0.1 \%$ DMSO for $24 \mathrm{~h}$. The control group under non-simultaneous treatment conditions was treated with $0.3 \%$ methanol for $24 \mathrm{~h}$ and then with $0.1 \%$ DMSO for $24 \mathrm{~h}$; the OA group was treated with $0.5 \mathrm{mM} \mathrm{OA}$ for $24 \mathrm{~h}$ and then with $0.1 \%$ DMSO for $24 \mathrm{~h}$. The bands of the western blots generated in our study were obtained from the same protein samples, but were not all run in the same experiment on the same gel. ${ }^{~} \mathrm{P}<0.05$ vs. control group; ${ }^{*} \mathrm{P}<0.05,{ }^{* *} \mathrm{P}<0.01$ vs. OA group. AMPK, 5'AMP-activated protein kinase; DAP, daphnetin; DMSO, dimethyl sulfoxide; OA, oleic acid; p, phosphorylated; PNPLA3, patatin-like phospholipase domain-containing protein 3; PPAR $\alpha$, peroxisome proliferator-activated receptor $\alpha$; SREBP-1C, sterol regulatory element-binding protein-1C.

cellular insulin sensitivity, and enhances the absorption and transport of glucose (38). The present study revealed that DAP increased the glucose uptake and the protein expression of pAKT/AKT in OA-treated HepG2 cells, suggesting that DAP could increase the hepatocellular insulin sensitivity by upregulating the protein expression of PI3K and the phosphorylation of AKT.

Excessive fat accumulation in the liver can induce hepatic lipid peroxidation and inflammation, which further aggravates hepatocellular IR, and can lead to irreversible fibrosis or cirrhosis of liver cells $(3,4)$. Therefore, oxidative stress may serve a determinant role in the development of NAFLD. The intracellular content of ROS reflects the oxidative stress levels of cells. ROS in the liver can be generated by mitochondria, peroxisomes and CYP enzymes (39). It has been reported that CYP2E1 and CYP4A can increase the production of hydrogen peroxide by the oxidation of long-chain fatty acids, and promote hepatocyte damage and steatohepatitis $(40,41)$.
The ROS-signaling pathway involves Nrf2, Kelch-like epichlorohydrin-related protein-1 and antioxidant response elements; this pathway serves a key regulatory role in oxidative stress (12). Shen et al (42) and Li et al (43) demonstrated that DAP possesses antioxidative and anti-inflammatory activities in vivo and in vitro. Our results indicated that DAP could alleviate oxidative stress damage by upregulating expression of Nrf2, and downregulating that of CYP2E1 and 4A in OA-treated HepG2 cells.

Of note, the bands of the western blots generated in our study were obtained from the same protein samples, but were not all run in the same experiment on the same gel; the experiment was conducted in triplicate. This may pose as a limitation of the present study; western blot bands presented together should all be obtained from the same membrane of the loading control for accurate analysis of protein expression.

DAP is an inhibitor of numerous pathways, including the epidermal growth factor receptor, protein kinase A and protein 

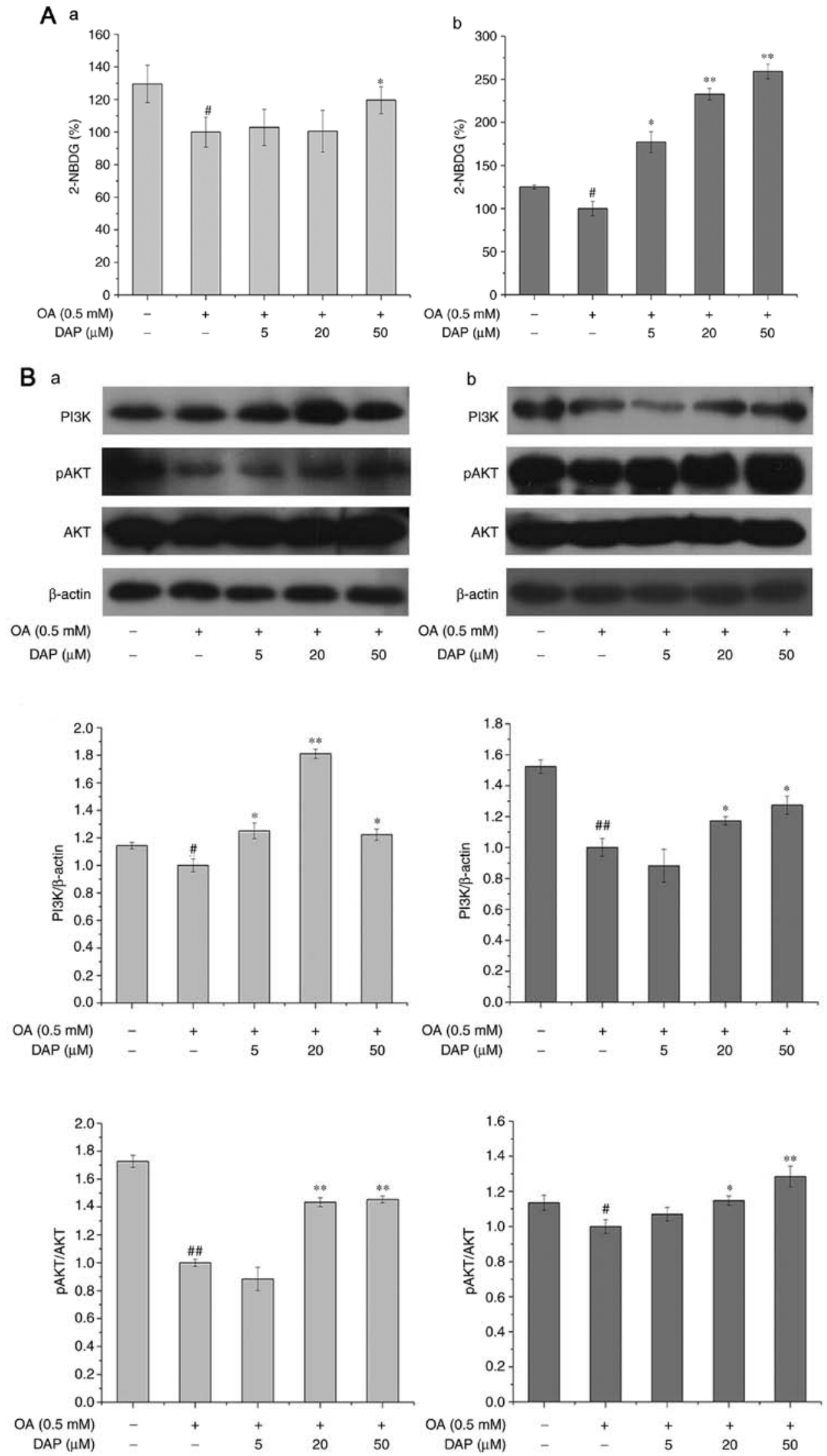

Figure 5. Effects of increasing DAP concentrations for $24 \mathrm{~h}$ on the cellular 2-NBDG, and the protein levels of PI3K and pAKT. (A-a) Glucose release following OA simultaneous treatment and (A-b) non-simultaneous treatment of HepG2 cells with OA and DAP. Protein expression of PI3K, AKT and pAKT following (B-a) simultaneous and (B-b) non-simultaneous treatment with OA and DAP. The control group in the simultaneous treatment condition was treated with $0.3 \%$ methanol and $0.1 \%$ DMSO for $24 \mathrm{~h}$; the OA group was treated with $0.5 \mathrm{mM} \mathrm{OA}$ and $0.1 \%$ DMSO for $24 \mathrm{~h}$. The control group in the non-simultaneous treatment condition was treated with $0.3 \%$ methanol for $24 \mathrm{~h}$ and then with $0.1 \%$ DMSO for $24 \mathrm{~h}$; the OA group was treated with $0.5 \mathrm{mM} \mathrm{OA}$ for $24 \mathrm{~h}$ and then with $0.1 \%$ DMSO for $24 \mathrm{~h}$. The bands of the western blots generated in our study were obtained from the same protein samples, but were not all run in the same experiment on the same gel. ${ }^{\#} \mathrm{P}<0.05,{ }^{\# \#} \mathrm{P}<0.01$ vs. control group; ${ }^{*} \mathrm{P}<0.05,{ }^{* *} \mathrm{P}<0.01$ vs. OA group. AKT, protein kinase $\mathrm{B}$; $\mathrm{p}$, phosphorylated; $\mathrm{PI} 3 \mathrm{~K}$, phosphoinositide 3-kinase; DAP, daphnetin; DMSO, dimethyl sulfoxide; OA, oleic acid. 
A a

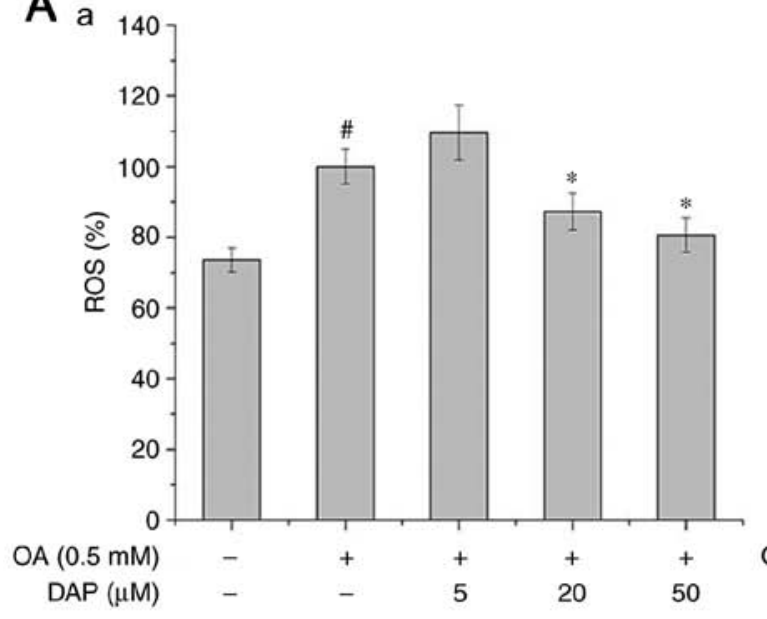

C

Nrf2

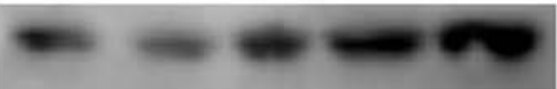

CYP 2E1

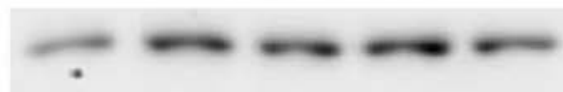

CYP 4A
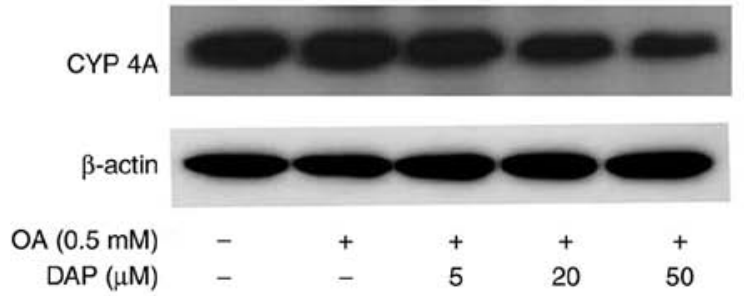

b 120

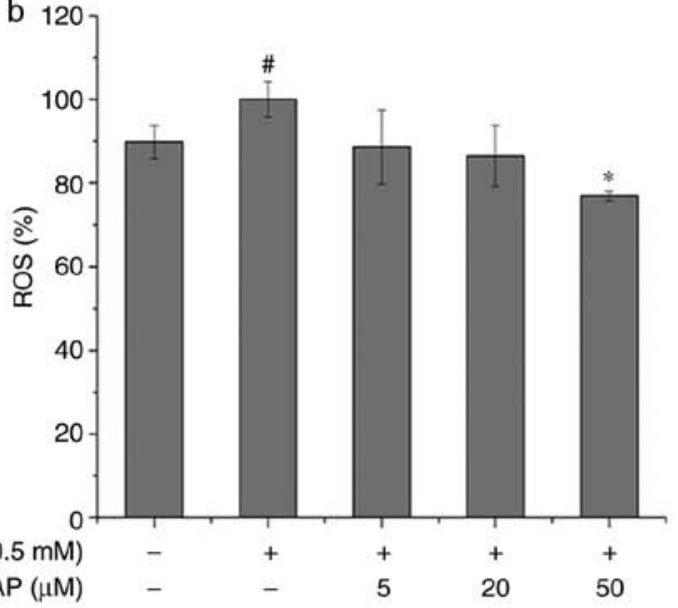

d

Nrf2

CYP 2E1

CYP 4A

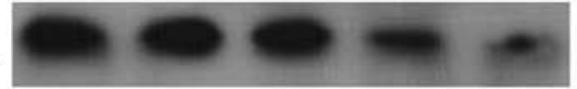

$\beta$-actin

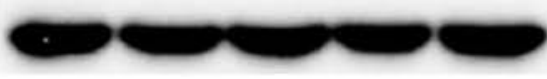

$\mathrm{OA}(0.5 \mathrm{mM}) \quad-\quad+\quad+\quad+\quad+$

$\operatorname{DAP}(\mu \mathrm{M}) \quad-\quad-\quad 5020 \quad 50$
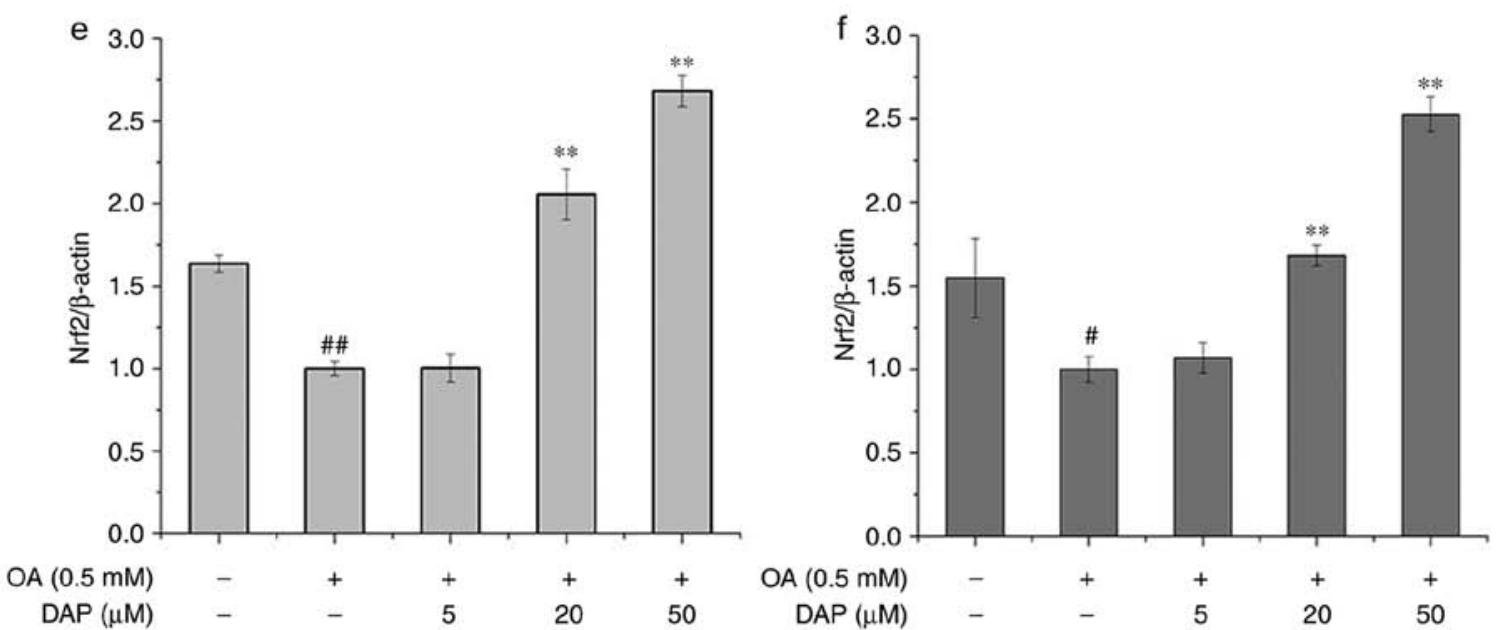

Figure 6. Effects of increasing DAP concentrations for $24 \mathrm{~h}$ on the cellular ROS and the protein levels of Nrf2, CYP2E1 and CYP4A. ROS levels were analyzed under (A-a) simultaneous treatment and (A-b) non-simultaneous treatment conditions. Western blot analysis following (A-c) simultaneous treatment and (A-d) non-simultaneous treatment. Densitometry analysis of (A-e and f) Nrf2. The control group in simultaneous treatment condition was treated with $0.3 \%$ methanol and $0.1 \%$ DMSO for $24 \mathrm{~h}$; the OA group was treated with $0.5 \mathrm{mM} \mathrm{OA}$ and $0.1 \%$ DMSO for $24 \mathrm{~h}$. The control group in the non-simultaneous treatment condition were treated with $0.3 \%$ methanol for $24 \mathrm{~h}$ and with $0.1 \%$ DMSO for $24 \mathrm{~h}$; the OA group was treated with $0.5 \mathrm{mM} \mathrm{OA}$ for $24 \mathrm{~h}$ and with $0.1 \%$ DMSO for $24 \mathrm{~h}$. The bands of the western blots generated in our study were obtained from the same protein samples, but were not all run in the same experiment on the same gel. ${ }^{\#} \mathrm{P}<0.05,{ }^{\# \#} \mathrm{P}<0.01$ vs. control group; ${ }^{*} \mathrm{P}<0.05,{ }^{* *} \mathrm{P}<0.01$ vs. OA group.

kinase $\mathrm{C}$ signaling pathways, Therefore, the association between AMPK, SREBP-1C, PNPLA3, PI3K, AKT, NRF2 and NASH suggested in the present study requires further investigation to determine the underlying mechanisms. The present study revealed that DAP could ameliorate lipid accumulation, IR and oxidative stress in OA-induced HepG2 cells (Fig. 7), demonstrating its possible application in ameliorating the various symptoms of NAFLD. Our results suggested the 

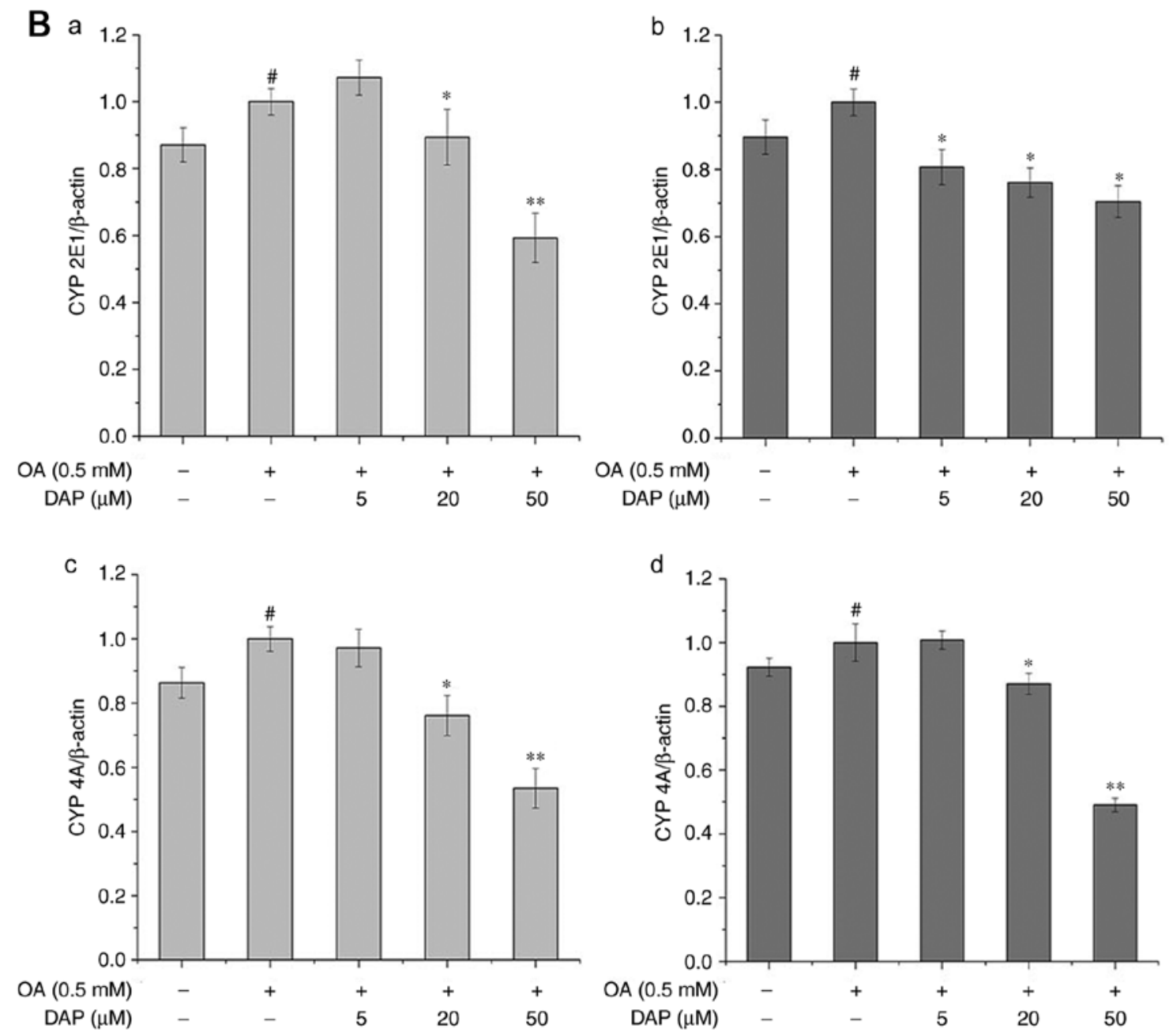

Figure 6. Continued. Effects of increasing DAP concentrations for $24 \mathrm{~h}$ on the cellular ROS and the protein levels of Nrf2, CYP2E1 and CYP4A. Densitometry analysis of (B-a and b) CYP2E1 and (B-c and d) CYP4A. The control group in simultaneous treatment condition was treated with $0.3 \%$ methanol and $0.1 \%$ DMSO for $24 \mathrm{~h}$; the OA group was treated with $0.5 \mathrm{mM} \mathrm{OA}$ and $0.1 \%$ DMSO for $24 \mathrm{~h}$. The control group in the non-simultaneous treatment condition were treated with $0.3 \%$ methanol for $24 \mathrm{~h}$ and with $0.1 \%$ DMSO for $24 \mathrm{~h}$; the OA group was treated with $0.5 \mathrm{mM} \mathrm{OA}$ for $24 \mathrm{~h}$ and with $0.1 \%$ DMSO for $24 \mathrm{~h}$. The bands of the western blots generated in our study were obtained from the same protein samples, but were not all run in the same experiment on the same gel. ${ }^{\#} \mathrm{P}<0.05,{ }^{\# \#} \mathrm{P}<0.01$ vs. control group; ${ }^{*} \mathrm{P}<0.05,{ }^{* *} \mathrm{P}<0.01$ vs. OA group. CYP, cytochrome P450; DAP, daphnetin; DMSO, dimethyl sulfoxide; Nrf2, nuclear factor-like 2; OA, oleic acid; ROS, reactive oxygen species.

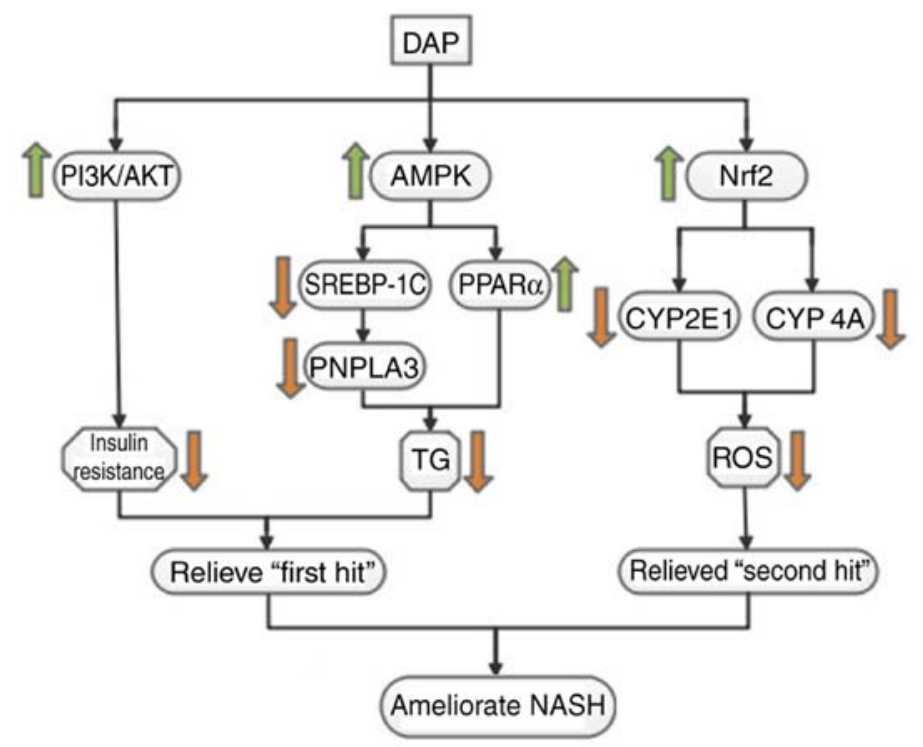

Figure 7. The potential mechanism of DAP on lipid metabolism, insulin resistance and oxidative stress in OA-treated HepG2 cells. 
potential mechanism underlying the effects of DAP against metabolic alterations in OA-treated HepG2 cells may involve the regulation of key factors involved in lipid metabolism (pAMPK, PPAR $\alpha$, SREBP-1C and PNPLA3), the insulin signaling pathway (PI3K-AKT) and oxidative stress (NRF2, CYP2E1, CYP4A).

\section{Acknowledgements}

Not applicable.

\section{Funding}

This research was supported by major technological innovation project of Hubei Province (grant no. 2016ACA140) and innovation and entrepreneurship training project for College Students of the Ministry of Education (grant no. 201610512001).

\section{Availability of data and materials}

The datasets used and/or analyzed during the current study are available from the corresponding author on reasonable request.

\section{Authors' contributions}

YL conducted the experiments under the non-simultaneous treatment conditions; LL performed the experiments under the simultaneous treatment conditions; FH and YC made substantial contributions to the design of the present study and revised the manuscript.

\section{Ethics approval and consent to participate}

Not applicable.

\section{Patient consent for publication}

Not applicable.

\section{Competing interests}

The authors declare that they have no competing interests.

\section{References}

1. Issa D, Patel V and Sanyal AJ: Future therapy for non-alcoholic fatty liver disease. Liver Int 38 (Suppl 1): S56-S63, 2018.

2. Suzuki A, Angulo P, Lymp J, St Sauver J, Muto A, Okada T and Lindor K: Chronological development of elevated aminotransferases in a nonalcoholic population. Hepatology 41: 64-71, 2005.

3. Tilg $\mathrm{H}$ and Moschen AR: Evolution of inflammation in nonalcoholic fatty liver disease: The multiple parallel hits hypothesis. Hepatology 52: 1836-1846, 2010.

4. Anstee QM and Goldin RD: Mouse models in non-alcoholic fatty liver disease and steatohepatitis research. Int J Exp Pathol 87: $1-16,2006$.

5. Review Team, LaBrecque DR, Abbas Z, Anania F, Ferenci $P$, Khan AG, Goh KL, Hamid SS, Isakov V, Lizarzabal M, et al: World gastroenterology organisation global guidelines: Nonalcoholic fatty liver disease and nonalcoholic steatohepatitis. J Clin Gastroenterol 48: 467-473, 2014.

6. Lee YH, Kim KJ, Yoo ME, Kim G, Yoon HJ, Jo K, Youn JC, Yun M, Park JY, Shim CY, et al: Association of nonalcoholicsteatohepatitis with subclinical myocardial dysfunction in non-cirrhotic patients. J Hepatol 68: 764-772, 2018.
7. Marra F, Gastaldelli A, Svegliati Baroni G, Tell G and Tiribelli C: Molecular basis and mechanisms of progression of non-alcoholic steatohepatitis. Trends Mol Med 14: 72-81, 2008.

8. Sumida Y and Yoneda M: Current and future pharmacological therapies for NAFLD/NASH. J Gastroenterol 53: 362-376, 2018.

9. Takahashi Y, Suqimoto K, Inui H and Fukusato T: Current pharmacological therapies for nonalcoholic fatty liver disease/nonalcoholic steatohepatitis. World J Gastroenterol 21: 3777-3785, 2015.

10. Liu J, Tian J, He W, Xie J, Hu Z and Chen X: Spectrofluorimetric study of the binding of daphnetin to bovine serum albumin. J Pharm Biomed Anal 35: 671-677, 2004.

11. Finn GJ, Creaven BS and Egan DA: Daphnetin induced differentiation of human renal carcinoma cells and its mediation by p38 mitogen-activated protein kinase. Biochem Pharmacol 67: 1779-1788, 2004.

12. Lv H,Liu Q, Zhou J, Tan G, Deng X and Ci X: Daphnetin-mediated Nrf2 antioxidant signaling pathways ameliorate tert-butyl hydroperoxide (t-BHP)-induced mitochondrial dysfunction and cell death. Free Radic Biol Med 106: 38-52, 2017.

13. Venugopala KN, Rashmi V and Odhav B: Review on natural coumarin lead compounds for their pharmacological activity. Biomed Res Int 2013: 963248, 2013.

14. Um MY, Moon MK, Ahn J and Youl Ha T: Coumarin attenuates hepatic steatosis by down-regulating lipogenic gene expression in mice fed a high-fat diet. Br J Nut 109: 1590-1597, 2013.

15. Yu W, Wang H, Ying H, Yu Y, Chen D, Ge W and Shi L: Daphnetin attenuates microglial activation and proinflammatory factor production via multiple signaling pathways. Int Immunopharmacol 21: 1-9, 2014.

16. Livak KJ and Schmittgen TD: Analysis of relative gene expression data using real-time quantitative PCR and the 2(-Delta Delta C(T)) method. Methods 25: 402-408, 2001.

17. Harrison SA, Oliver D, Arnold HL, Gogia S and Neuschwander-Tetri BA: Development and validation of a simple NAFLD clinical scoring system for identifying patients without advanced disease. Gut 57: 1441-1447, 2008.

18. Vacca M, Allison M, Griffin JL and Vidal-Puig A: Fatty acid and glucose sensors in hepatic lipid metabolism: Implications in NAFLD. Semin Liver Dis 35: 250-261, 2015.

19. Szczepaniak LS, Nurenberg P, Leonard D, Browning JD, Reingold JS, Grundy S, Hobbs HH and Dobbins RL: Magnetic resonance spectroscopy to measure hepatic triglyceride content: Prevalence of hepatic steatosis in the general population. Am J Physiol Endocrinol Metab 288: E462-E468, 2005.

20. Kanuri $G$ and Bergheim I: In vitro and in vivo models of non-alcoholic fatty liver disease (NAFLD). Int J Mol Sci 14: 11963-11980, 2013

21. Rafiei H, Omidian K and Bandy B: Comparison of dietary polyphenols for protection against molecular mechanisms underlying nonalcoholic fatty liver disease in a cell model of steatosis. Mol Nutr Food Res 61, 2017.

22. Xie C, Chen Z, Zhang C, Xu X, Jin J, Zhan W, Han T and Wang J: Dihydromyricetin ameliorates oleic acid-induced lipid accumulation in L02 and HepG2 cells by inhibiting lipogenesis and oxidative stress. Life Sci 157: 131-139, 2016.

23. Fan JG, Wei L and Zhuang H; National Workshop on Fatty Liver and Alcoholic Liver Disease, Chinese Society of Hepatology, Chinese Medical Association; Fatty Liver Disease Expert Committee, Chinese Medical Doctor Association: Guideline of prevention and treatment of nonalcoholic fatty liver disease (2018, China). J Dig Dis, Nov 16, 2018 (Epub ahead of print).

24. Smith BK, Marcinko K, Desjardins EM, Lally JS, Ford RJ and Steinberg GR: Treatment of nonalcoholic fatty liver disease: Role of AMPK. Am J Physiol Endocrinol Metab 311: E730-E740, 2016.

25. Kohjima M, Higuchi N, Kato M, Kotoh K, Yoshimoto $T$, Fujino T, Yada M, Yada R, Harada N, Enjoji M, et al: SREBP-1c, regulated by the insulin and AMPK signaling pathways, plays a role in nonalcoholic fatty liver disease. Int J Mol Med 21: 507-511, 2008.

26. Ruderman NB, Carling D, Prentki M and Cacicedo JM: AMPK, insulin resistance, and the metabolic syndrome. J Clin Invest 123: 2764-2772, 2013.

27. Ahmed MH and Byrne CD: Modulation of sterol regulatory element binding proteins (SREBPs) as potential treatments for non-alcoholic fatty liver disease (NAFLD). Drug Discov Today 12: 740-747, 2007. 
28. Dubuquoy C, Robichon C, Lasnier F, Langlois C, Dugail I, Foufelle F, Girard J, Burnol AF, Postic C and Moldes M: Distinct regulation of adiponutrin/PNPLA3 gene expression by the transcription factors ChREBP and SREBP1c in mouse and human hepatocytes. J Hepatolv 55: 145-153, 2011.

29. Seo YS, Ji HK, Jo NY, Choi KM, Baik SH, Park JJ, Kim JS, Byun KS, Bak YT, Lee $\mathrm{CH}$, et al: PPAR agonists treatment is effective in a nonalcoholic fatty liver disease animal model by modulating fatty-acid metabolic enzymes. J Gastroenterol Hepatol 23: 102-109, 2008

30. Zheng T, Yang X, Wu D, Xing S, Bian F, Li W, Chi J, Bai X, $\mathrm{Wu} G$, Chen X, et al: Salidroside ameliorates insulin resistance through activation of a mitochondria-associated AMPK/PI3K/Akt/GSK3 $\beta$ pathway. Br J Pharmacol 172 3284-3301, 2015

31. Sanyal AJ, Campbellsargent C, Mirshahi F, Rizzo WB Contos MJ, Sterling RK, Luketic VA, Shiffman ML and Clore JN: Nonalcoholic steatohepatitis: Association of insulin resistance and mitochondrial abnormalities. Gastroenterology 120 1183-1192, 2001.

32. Gastaldelli A, Cusi K, Pettiti M, Hardies J, Miyazaki Y, Berria R, Buzzigoli E, Sironi AM, Cersosimo E, Ferrannini E and Defronzo RA: Relationship between hepatic/visceral fat and hepatic insulin resistance in nondiabetic and type 2 diabetic subjects. Gastroenterology 133: 496-506, 2007.

33. Bugianesi E, Gastaldelli A, Vanni E, Gambino R, Cassader M, Baldi S, Ponti V, Pagano G, Ferrannini E and Rizzetto M: Insulin resistance in non-diabetic patients with non-alcoholic fatty liver disease: Sites and mechanisms. Diabetologia 48: 634-642, 2005.

34. Dunaif A: Insulin resistance and the polycystic ovary syndrome: Mechanism and implications for pathogenesis. Endocr Rev 18: 774-800, 1997.

35. Hotamisligil GS, Shargill NS and Spiegelman BM: Adipose expression of tumor necrosis factor-alpha: Direct role in obesity-linked insulin resistance. Science 259: 87-91, 1993
36. Yamauchi T, Kamon J, Waki H, Terauchi Y, Kubota N, Hara K, Mori Y, Ide T, Murakami K, Tsuboyama-Kasaoka N, et al: The fat-derived hormone adiponectin reverses insulin resistance associated with both lipoatrophy and obesity. Nat Med 7: 941-946, 2001.

37. Shoelson SE, Lee J and Goldfine AB: Inflammation and insulin resistance. J Clin Invest 116: 1793-1807, 2006.

38. Sharma BR, Kim HJ and Rhyu DY: Caulerpa lentillifera extract ameliorates insulin resistance and regulates glucose metabolism in $\mathrm{C} 57 \mathrm{BL} / \mathrm{KsJ}-\mathrm{db} / \mathrm{db}$ mice via PI3K/AKT signaling pathway in myocytes. J Transl Med 13: 62, 2015.

39. Sanyal AJ, Campbellsargent C, Mirshahi F, Rizzo WB Contos MJ, Sterling RK, Luketic VA, Shiffman ML and Clore JN: Nonalcoholic steatohepatitis: Association of insulin resistance and mitochondrial abnormalities. Gastroenterology 120: 1183-1192, 2001

40. Rao MS and Reddy JK: Peroxisomal beta-oxidation and steatohepatitis. Semin Liver Dis 21: 43-55, 2001.

41. Schattenberg JM and Czaja MJ: Regulation of the effects of CYP2E1-induced oxidative stress by JNK signaling. Redox Biol 3: 7-15, 2014.

42. Shen L, Zhou T, Wang J, Sang X, Lan L, Luo L and Yin Z: Daphnetin reduces endotoxin lethality in mice and decreases LPS-induced inflammation in Raw264.7 cells via suppressing JAK/STATs activation and ROS production. Inflamm Res 66: 579-589, 2017.

43. Li M, Shi X, Chen F and Hao F: Daphnetin inhibits inflammation in the NZB/W F1 systemic lupus erythematosus murine model via inhibition of NF- $\kappa B$ activity. Exp Ther Med 13: 455-460, 2017.

This work is licensed under a Creative Commons Attribution-NonCommercial-NoDerivatives 4.0 International (CC BY-NC-ND 4.0) License. 